\title{
Economic Mechanisms Explaining Low Wages in the Personal Services Sector
}

An Analysis Focusing on Home Help Workers

François-Xavier Devetter and Emmanuelle Puissant

Translator. Patrick Hamm

\section{(2) OpenEdition}

1 Journals

Electronic version

URL: http://journals.openedition.org/travailemploi/10026

DOI: 10.4000/travailemploi.10026

ISSN: 1775-416X

Publisher

DARES - Ministère du Travail

\section{Printed version}

Date of publication: 1 March 2020

Number of pages: 53-84

ISSN: 0224-4365

\section{Electronic reference}

François-Xavier Devetter and Emmanuelle Puissant, "Economic Mechanisms Explaining Low Wages in the Personal Services Sector", Travail et Emploi [Online], Hors-série | 2020, Online since 01 March 2021, connection on 30 April 2021. URL: http://journals.openedition.org/travailemploi/10026 ; DOI: https:// doi.org/10.4000/travailemploi.10026 


\title{
Economic Mechanisms Explaining Low Wages in the Personal Services Sector
}

\author{
An Analysis Focusing on Home Help Workers
}

\author{
François-Xavier Devetter, ${ }^{* *}$ Emmanuelle Puissant ${ }^{* * *}$
}

\begin{abstract}
The purpose of this article is to show how low wages in home help services, a sector where jobs are considered "low-skilled", result from an array of mechanisms that themselves are the fruit of a socio-political and socioeconomic construction. These mechanisms flow from both public and private strategies, which we seek to clarify by synthesising empirical work in the field of personal services. Three mechanisms involved in the non-recognition of these professions are identified (denying or reducing the "qualities" used; developing an abundant labour supply; and dividing the workforce), with each of these being applied in both national policy guidelines and employer human resources strategies. The home help sector appears to be illustrative of trends at work in many other highly feminised service activities (cleaning, hotel and catering, and retail).
\end{abstract}

\footnotetext{
Changes in employment over the last thirty years have been characterised by growing inequalities in income and skills. The development of a "knowledge economy" has undoubtedly led to an increase in highly qualified jobs (managers and engineers), but it has also been accompanied by the preservation or even renewal of low-skilled jobs (MÉDA, VENNAT, 2004). This phenomenon of job polarisation has been studied in the United States as well as in Europe (JOLLY, 2015), from the point of view of changes in both job quality (FERNANDEZ-MACIAS, 2012) and job qualifications (OEsCh, MENES, 2011). Studies have also been conducted more specifically in France (Ast, 2015), but these have often focused on the technological transformations that have affected industry in particular. With a few exceptions (DWYER, 2013), the

* Traduction: Patrick Hamm. Article published in French in Travail et Emploi, no 155-156, 2018.

** Université de Lille, Centre lillois d'études et de recherches sociologiques et économiques (CLERSÉ); Lille Douai; francois-xavier.devetter@imt-lille-douai.fr.

*** Université Grenoble Alpes, Centre de recherche en économie de Grenoble (CREG); emmanuelle.puissant@ univ-grenoble-alpes.fr.
} 
specificities of women's occupations, mainly in services, have not been at the heart of analysis of job polarisation.

The focus of this article is precisely on a segment of this so-called "unskilled" labour market, in services where women are strongly represented: the segment of personal services activities $\left(\mathrm{PSA}^{1}\right.$ ), and in particular jobs as home helps ${ }^{2}$ (Box 1). Like other activities identified from the Working Conditions survey (enquête Conditions de travail) carried out by the French Ministry of Labour's statistics and research section, the Direction de l'animation de la recherche, des études et des statistiques (DARES) in 2013, such as cleaners, waiters and kitchen helps, clothing salespeople, service representatives, etc., these activities are particularly degraded segments of the labour market, combining precariousness, low pay, a lack of training or career prospects, and often harsh working conditions (CAROLI, GaUtié, 2009; CARrÉ, Tilly, 2012; KALLEBERG, 2011). Far from shrinking, this segment of the labour market has been expanding, and includes jobs with high recruitment prospects (ABOUBADRA et al., 2014) but few real improvements in the level of wages.

Although the statistical categorisation of unskilled employees has not fully stabilised (Burnod, ChENu, 2001; AMOSSÉ, ChARDON, 2006; Rose, 2012), many service jobs seem to belong to this type of category, whose position at the bottom of the scale is traditionally explained by three self-sustaining mechanisms. First, the low productivity of these jobs justifies only low pay (CAHUC, 2001). France's minimum wage (Salaire minimum interprofessionnel de croissance, SMIC) may even be higher than the wage level that these jobs' marginal productivity should imply, which would then justify specific subsidies $^{3}$ (BLANCHET, RAVALET, 1995). Second, since the skills needed are widespread in the population, the potential labour supply is abundant, which pulls the market wage downwards, especially in periods of high unemployment. Finally, in terms of industrial relations, since work is often dispersed, these occupations are marked by a lower level of collective organisation and unionisation than found in other sectors (Western, Healy, 1999).

\footnotetext{
1. Home help activities are activities carried out in the private homes of so-called fragile people (elderly people, disabled people, families considered to be in difficulty). These activities are considered to belong to social and medico-social activities under the Law of 2 January 2002 renovating social and medico-social action, and have been included in the field of personal services since the Borloo social cohesion plan of 2005. This field of PSAs is now much broader and includes home helps, do-it-yourself activities (DIY), computer assistance, and home gardening. Home help for dependent persons accounts for more than 57\% of the activity of PSA agencies, with housekeeping at $26.3 \%$, and DIY/gardening and childcare at about 5\% each (KulANTHAIVELU, 2018). Most employed home helps do not have a diploma related to the sector, and even the State diploma for homecare assistants (Diplôme d'État d'auxiliaire de vie sociale, DEAVS) remains rare (TRABUT, 2014).

2. This article will focus on the home help sector, in which professions, training, and diplomas have historically been constructed. The field of personal services will also be addressed, insofar as the creation of the market for personal services is part of a public strategy to legitimise low wages in all the activities that fall within its scope.

3. In parallel, the relatively high level of the minimum wage (in absolute terms and in terms of the ratio of minimum wage to median wage) may lead employers to "compensate" by intensifying work and/or investing less in the nonwage dimensions of job quality. Ève CAROLI and Jérôme GAUTIÉ (2009) thus explain the French paradox of low-wage workers who are relatively well paid compared with their counterparts in other European countries, but who are more dissatisfied with their wages because, according to European surveys, they are subject to harsher working conditions.
} 


\section{Box 1 \\ From Home Care to Personal Services: The Evolution of a Sector under Public Policy Pressure}

While, since the 2005 Borloo plan, personal services have included a heterogeneous set of activities with very different histories, logics, and regulations (DEVETTER et al., 2015), home help activities have had a certain historical, statistical, professional, and legislative consistency. Home help is defined here on the basis of the collective agreements covering all the services aimed at a fragile public (elderly or disabled people, families in difficulty) that are provided in the beneficiaries' private homes. The first home help enterprises were associations formed at the end of the 1940s. The first collective agreements date back to 1970 and grew especially during the 1980s, in the dual sense that they multiplied in number and became more comprehensive. They were subsequently supplemented by branch agreements, particularly in the 1990s. During the 2000s, the three collective agreements in the private non-profit sector merged, and a new collective agreement was created, covering for-profit personal services companies.

The sector was opened to competition in 1996 and has mushroomed since 2005. Today it is characterised by the coexistence of two types of employment and four types of employers (diagram below). This situation grew out of a process that began in the 1980s, aimed at developing family jobs as a means of reducing unemployment by creating local jobs that are considered accessible with no need for special qualifications. Employment policies and policies allowing social security and tax exemptions have expanded strongly in this field.

These three mechanisms are evidenced by well-documented empirical findings. These socio-economic processes come together to naturalise the situation of home help workers and thereby legitimise the maintenance of low wages. Low job productivity, the existence of an abundant labour supply, and the dispersion of the workforce are not data that emerge spontaneously but are, on the contrary, the consequence of public policies and human resource management strategies that are more or less intentional. These have been the subject of in-depth analyses of industrial jobs, which have highlighted de-skilling mechanisms ${ }^{4}$ affecting skilled workers (BRAVERMAN, 1976; HAAKKESTAD, FRIDBERG, 2017), the existence of an "industrial reserve army" (MARX, 1867), and mechanisms to divide the workforce (MARGLIN, 1974; GoRDON et al., 1982; PERRAUdin et al., 2006).

The purpose of this article is to use a socio-economic approach to bring to light the processes corresponding to these economic mechanisms, in terms of both their content and their perpetuation and growth, so as to explain the maintenance of low

4. "De-skilling" is understood here to mean a dual process involving the downplaying or non-recognition of the skills used, on the one hand, and the suppression of the skills used through the development of tools or forms of job organisation that reduce the autonomy of the professionals, on the other hand. 
wage levels. The article is based on a synthesis of empirical work in the field of personal services, and mainly on home help. The first mechanism (low pay) involves denying or downplaying the "qualities" employees make use of in their daily work. Doing this has a dual meaning: downplaying these qualities, but also de-skilling (BRAVERMAN, 1976), i.e. the suppression of these qualities, in particular through methods of work organisation. This article will focus primarily on the first aspect. The second mechanism concerns the construction of an abundant labour supply, the objective of which is to maintain an imbalance between supply and demand in favour of the demand for labour, i.e. of employers. Finally, the third mechanism identified consists in dividing the workforce, by heightening competition and weakening work collectivity, in order to reduce people's capacity for expression (Table 2, p. 74, summarises these different elements). Our analysis is based mainly on our previous empirical studies, on the home help professions and occasionally on other professions at the lower end of the pay scale, where the mechanisms identified are found to be structural. This approach makes it possible to highlight the heuristic virtue of the home help sector in understanding the functioning of degraded segments of the labour market (Box 2).

\section{Box 2}

\section{Methodology used}

This contribution has a theoretical objective: it aims to synthesise the processes contributing to non-recognition of the wages and symbolic value of the home help professions. It is based on ten empirical studies carried out in this field between 2008 and 2017. This is mainly material covering the home help sector, but the cleaning sector and early childhood professions are also addressed. A total of 442 semi-directive interviews were conducted with employees, employers, and regulators in these fields of activity (see the appendix for a list of studies and interviews). Specific insights into other sectors are drawn on when the mechanisms identified have been observed there as well.

\section{Denial of Competence and Hardship}

At the heart of theories of neo-classical inspiration used to explain wage differentials are human capital theory and hedonic wage theory. In the first, differences in pay are said to compensate for the direct and indirect costs of acquiring human capital and are explained by differences in productivity (approximated by differences in training or qualifications), whereas in the second case it is the arduousness or hardship endured that is used to justify wage differentials.

However, low pay is due not so much to a low level of these two aspects of employment (qualifications and hardship) as to a lack of social recognition. In fact, 
making the link between these two dimensions of a job and its compensation requires that the levels of both hardship and qualifications be well established. Such social recognition does not emerge spontaneously, but depends on the will of those concerned. However, in the field of personal services, the lack of valorisation is an issue, as is, upstream, the recognition of the very existence of the skills used and the hardships endured.

\section{Naturalisation of Skills}

The negation of skills has been examined in depth by sociological and economic studies on women's occupations, both in industry (GUILBERT, 1966; MARUANI, NICOLEDrANCOURT, 1989) and in services (DUSSUET, 1997; GADREY et al., 2004; 2009; FOLBRE, 2001; BUDIG et al., 2002).

The mechanisms highlighted in this work support an initial logic, which consists of not considering the competencies required to be identifiable or objectifiable. These are instead presented as "natural", as characteristics of people's "savoir-être". Above all, as they are not formalised, they cannot constitute an "entry barrier". The skills and qualities used are then considered to be widely shared because they are to a great extent acquired in the private and informal sphere, within the framework of a socialisation process marked by the weight of gender (from men's strength to women's meticulousness). As a result, the required skills are not transmitted in specific training schools, which blocks their objectification and visibility. Another process favouring the broad sharing of these supposedly non-specific skills stems from technical and organisational mechanisms that reduce the work to a succession of simple routines or attitudes. This process has been particularly well studied in the context of implementing a scientific approach to the organisation of labour - in a logic close to that described by Harry BRAVERMAN (1976) in industry - in highly Taylorised services such as fast food (NKOUATCHET, 2005). This has been emerging more recently in services that are more "relational", such as personal services, and is based on the development of certified quality standardisation procedures and mechanisms associated with increased control of the workforce, or even a devaluation of certain "lay" skills (CRESSON, 2006). There have been intense conflicts around the recognition of skills and their certification but, at the same time, explicit disqualification mechanisms can be observed. Two examples can be used to illustrate these processes: on the one hand, the recruitment methods for childminders and, on the other hand, the decisions made by public policy makers and employers regarding home help.

The situation of childminders is particularly emblematic. The progressive structuring of the profession and the growth of public regulation (TIRMARCHE-ISSEMANN, 2011) have not been accompanied by the promotion of training (initial or continuing) which, "although it is considered interesting or even useful, is rarely perceived as necessary, let alone indispensable" (ABALlÉA, 2005, p. 60). For example, the requirement to enrol in the compulsory "Child care in the home" module for France's certificate of professional competence in early childhood skills (Certificat d'aptitude 
professionnelle) does not imply any requirement that the tests be validated. Qualitative surveys highlight the contradictions of both public authorities and parent employers, who oscillate constantly between recognition of the "remarkable work" done by these employees and the insistence on making this profession accessible to all, with no barriers to entry, in the name of the necessary fight against unemployment. This dissonance between two opposing objectives, valuing the "job of motherhood" and the desire for a professional framework, produces a situation in which recruitment procedures resemble a social selection process that draws on the socio-demographic characteristics of the employees (place and setting of the home, appearance, etc.; cf. VOZARI, 2014), involving criteria that are too implicit to be legitimised. This refusal to give social recognition to the qualities used can be explained in part by the fact that the community agrees to pay these professionals only very little (one-third of the minimum hourly wage for care of a child). Jeanne FAGNANI and Antoine MATH (2012) have shown, on the basis of econometric analyses, that employer parents were in general not willing to pay a higher salary to someone with higher qualifications. This is confirmed by the fact that seniority is hardly ever valued in collective agreements.

In the case of home help, public policies have positioned themselves in favour of professionalising jobs and occupations. However, this willingness has been both belated and ambivalent (PUISSANT, 2011). Belated, because in the case of home help for the elderly, France's first national diploma for this job (the Certificat d'aptitude aux fonctions d'aide à domicile) dates from 1990, and the first State diploma (DEAVS) dates from 2002, whereas the Certificate of aptitude for care assistants (Certificat d'aptitude aux fonctions d'aide-soignant), for example, has existed since 1956. The attitude of the public authorities has been ambivalent, because although the State diploma is a considerable step forward in the recognition of the qualified nature of certain professions in the sector, ${ }^{5}$ the fact that it is optional for carrying out home help greatly reduces its scope, both symbolically and materially (DusSUET, PUISSANT, 2015). Moreover, this diploma is recognised by only one type of employer (associations in the non-profit sector). It is not taken into account in the classifications in other collective agreements (those of private employers, for-profit companies, and municipal and intermunicipal social work centres). The ambivalent nature of this professionalisation with respect to the recognition of qualifications is undoubtedly the result of an attempt to reconcile two social representations related to ageing, which lead to significantly different public policy objectives: one concerns the need to develop skilled jobs in the medico-social sector of care for the elderly, and the other concerns the desire to keep down the public cost of care for old-age dependency.

Employers and the human resource (HR) policies put in place in home help agencies also play a role in the process of naturalising skills. Interviews with employers show that the recruitment criteria used often relate to the gender characteristics of the candidates, their extra-professional status (in particular as mothers or daughters),

5. The creation and increased take-up of the DEAVS diploma since 2002 has been accompanied by a significant increase in the average wage levels of home helps, although wages remain very low (DEVETTER et al., 2017). 
or their demonstrated "time availability", but much less often to the qualifications they have acquired (DEvetTer, Rousseau, 2009). Likewise, access to training for employees is relatively modest in this sector and is still very dependent on the status of the employer: very limited for employees of private employers, a little less so for those of service providers (Table 1). In any case, however, the portion of non-qualifications training remains predominant, as the HR director of one association points out:

"The most important thing in training is that employees realise the complexity of what they are being asked to do... Do you encourage employees to get the DEAVS diploma? Oh no, no! If they want to, no problem of course, the validation of acquired experience [Validation des acquis de l'expérience, VAE] is a right! But we don't ask for it, it's not really necessary. Besides, with our hourly rate it'd be impossible for all the employees working in the homes of sick people to have diplomas! [laughter]"

(Interview with the HR director of an association in Rhône-Alpes, 2011 [Lamotte, Puissant, 2013])

This outlook is also quite frequently taken up by the employees themselves, who even go so far as to declare that they don't reveal possessing a diploma:

"I knew that if I told them [I had the DEAVS], they wouldn't take me, I would have cost too much. It happened to a colleague, so I didn't want to take the risk."

(Statement by an employee of an association in the Drôme area, during a meeting on population ageing, 2008 [LAMOtTe, Puissant, 2010])

Employers thus often perceive a diploma as implying an additional wage cost and a risk of leaving (for example for jobs in residential care facilities such as nursing homes for elderly dependents [Établissements d'hébergement pour personnes âgées dépendantes, Ehpad]) rather than as an opportunity to improve work and service quality. This may help to explain the low level of training in enterprises and associations and its virtual absence in direct employment (Table 1).

\section{TABle 1 - Training in the Personal Services Sector}

\begin{tabular}{lccc}
\hline & $\begin{array}{c}\text { Private service } \\
\text { provider } \\
\text { (association } \\
\text { or company) }\end{array}$ & Public sector & $\begin{array}{c}\text { Individual } \\
\text { employer }\end{array}$ \\
\hline $\begin{array}{l}\text { Attendance of formal training during the four } \\
\text { weeks preceding the survey (FORMEL) }\end{array}$ & 2 & 4 & 0.5 \\
$\begin{array}{l}\text { Attendance of a course or internship during the last } \\
\text { three months (COURSTAG) }\end{array}$ & 10 & 12 & 1 \\
$\begin{array}{l}\text { Participation in courses, conferences or seminars } \\
\text { in the last three months (SEMCONF) }\end{array}$ & 1 & 2.5 & 0.5 \\
$\begin{array}{l}\text { This training has been at least partially completed } \\
\text { during working time (LWORHA, if the person is } \\
\text { or has been undergoing training) }\end{array}$ & 53 & 62 & 5 \\
\hline
\end{tabular}

Field: Employed home help workers and domestic workers $(\mathrm{N}=6,522)$.

Source: Employment survey (enquête Emploi, 2015), INSEE. 


\section{Hardships that are Denied and Lack Compensation}

Rendering skills invisible in this way is also found in regard to the arduousness of the work and working conditions. Indeed, the institutional frameworks for seeing and recognising working and employment conditions were constructed in the context of the "wage society" (CASTEL, 1995), which is rather industrial and male. However, the tertiarisation and feminisation of work and employment represent major challenges in terms of renovating these analytical frameworks. Thus, while arduous so-called "industrial" tasks are nowadays rather well referenced and detailed in statistical nomenclatures, collective agreements, and branch agreements, the same cannot be said for arduous so-called "tertiary" tasks that are linked to the "service relationship", in the sense accorded them by Jean GADREY (2003). However, recent work has attempted to characterise these forms of hardship (DEVETTER, MESSAOUdi, 2013) and the associated occupational risks (Dussuet, 2013).

Home help is thus a sector that is highly exposed to occupational accidents and illnesses, with more than 47 days off work per million hours worked, compared to an average of 33 days off for all employees (CNAMTS, 2016). The arduous nature of the work is due in particular to the large number of journeys made between two interventions in the course of the same day, as the following two interview extracts show:

"We've got 15 minutes to get to the people's home. So today, let's say, I'm working in my sector. I'll do half an hour there and then I'll race over to the other side. Now they're no longer arranging us like they used to. So before I had, like one person. Sometimes I do somebody on one side of the sector and later I go back there and then afterwards I go back to the other side. So, like that, you're running..."

(Home help, woman, 2016 [DEVETTER et al., 2016])

“- On weekends, it's only half hours, it's actually for meals... Sometimes I do 9h30 over the course of a day.

Q: - And you have two-hour interventions?

- Ah, almost never, there's no... The maximum is one hour. And apart from Monday afternoon at this one woman's, I have from 2:15 to 2:45. That's when I do my shopping."

(Home help, woman, 2016 [DevetTer et al., 2016])

However, public regulation of the sector and the way it is financed (by the user paying an hourly tariff that remains relatively low) does not encourage better consideration of these professional risks. It does not, for example, make it possible to correctly integrate the time considered as "non-productive" (between shifts in particular), which contributes to intensifying work and making it more difficult to carry out. Similarly, occupational medicine plays only a partial role in relation to home helps. First, it covers only a small proportion of salaried employees (private individuals' employees are not covered at all). Second, for those employees it does cover, the occupational physician cannot access the workplace (private homes), and the same holds for the labour inspectorate. Finally, the occupational medicine staff often come into play late 
in the day (there are few prevention policies) and in a way that is very complex for the structures to manage: faced with the health difficulties encountered by employees, the occupational physician may recommend "partial incapacity" (for example, not to carry loads of more than $5 \mathrm{~kg}$ ); however, these medical decisions are in fact incompatible with practices in the profession, and are regularly criticised by the employers we were able to interview. The organisation of work together with HR policies have the effect of putting the hardships into perspective. Studies of associations in general (HÉLY, 2009), and of home help associations in particular (Dussuet, 2005; PuISSANT, 2010), have highlighted the predominance of service to the users, to the detriment of employee working conditions. Our surveys show that the organisation of labour can also be a factor in aggravating hardship: failure to take this into account can lead employers to develop job organisation schemes and HR policy tools that increase work rates:

"We just do our best, that's all, but often we're overwhelmed: with the half hour they give us, we can't do everything, it's just not possible. No, we just can't. Often, if something is missing, you just have to run out and buy it quickly, when the shop's not far away, it's good, but when it's further away, you can't. And besides, as soon as the time is up, what do we do with people?"

(Home help, woman, 2016 [DEvETTER et al., 2016])

The fragmentation of labour is a factor involved in hardship and increased occupational risk: the danger of road accidents in particular is multiplied, as well as, more generally, the risk of a deterioration in the state of employee health:

"But it wasn't permanent, the stress, it was afterwards in the end, the stress was the time, the distances I had to ride my bike. The distances, because I had ten interventions in one day and that was it. No time to eat, no time to go home for lunch...."

(Home help, woman, dismissed for unfitness following a bicycle accident between two interventions [DEVETTER et al., 2016])

The trend towards an increase in the number of interventions of less than one hour in the homes of the elderly is increasing this fragmentation, which is further reinforced by the spread of time control methods via remote management tools (DussuET et al., 2017).

This process is also at work in other professions, such as cleaners (especially women), who suffer from the invisibility of the hardships they endure. Karen MEsSING and her co-authors $(1993,1998)$ thus analyse in depth how tasks considered less physically difficult (known as "light work") often involve constraints that are just as or even more intense than work initially viewed by employers and clients as more demanding (so-called "heavy" work): the reality of working conditions thus differs markedly from their ex ante characterisation by management. Similarly, exposure to chemical substances remains largely invisible in these jobs, in which toxic products (various sprays, bleaches, descalers, etc.) are very commonplace, even though their impact on health is now well established by scientific work (Zock, 2005, for example). 
These sectors even have the highest number of occupational accidents and illnesses: the number of accidents per million working hours thus reaches 52 in the routine cleaning of buildings and 75 in home help, compared to an average of 23 for all employees covered by the general occupational health scheme and 39 in the building and public works sector (CNAMTS, 2016). However, analysis of the statistical data relating to the home help and cleaning professions shows a significant discrepancy between the reporting of some arduous work (the perceived work rate is thus rather low) and employees' state of health. The link between working conditions and health status is poorly assessed, as employees seem to under-report the arduousness of their work. Several studies have highlighted the importance of gender in this underestimation of arduousness (GollaC, VOLKOFF, 2006), which can contribute to degraded and uncompensated work situations on the labour market: if female employees fail to feel the actual hardship and to express this in a collective manner, these jobs will not be compensated, in particular by a salary higher than the minimum wage. Employees then wind up dealing with their capacity for resistance individually: the generalised use of part-time work appears to be one way of "holding on" to a job that is nonetheless very arduous. This kind of strategy also exists in other sectors, notably, the case of female agricultural workers who opt for employment on successive fixed-term contracts (Contrat à durée déterminée) in order to have breaks between two contracts (Roux, 2018).

\section{Construction of an Excess Labour Supply}

The logics that we have described above legitimise the assertion that there is no need for specific qualifications and, consequently, no remuneration for them. This logic therefore removes possible "entry barriers" to certain professions and facilitates the emergence of mechanisms leading to the expansion of the labour supply (without having to resort to the classic channels of raising wages and developing training), because the social perception of the service provided (characterised by a very low willingness to pay) prevents the work underlying these services from being assigned a market wage higher than the minimum wage. This work, socially necessary but with no market value, must be offered by a "prompted" workforce. It is then necessary to orient enough people to these occupations and to "put to work" the men, and frequently the women, who "should" accept these jobs. In order to understand this phenomenon, two main approaches are discussed here, with a distinction made between the role of public policy and that of employer strategies: what is involved is putting specific categories of labour to work and subsidising this "unproductive" labour (on both the labour supply side and the demand side concerned by these services). 


\section{Putting to Work "Under-Mobilised” Groups: Mothers and Immigrants}

The first way to expand the labour supply is to encourage the activity of certain categories of people perceived as "underemployed". The exploitation of pools of labour is necessary as soon as a large volume of job vacancies is identified because, in the absence of a new labour supply, pressure on hiring could arise and push up wages. From this point of view, it is rather paradoxical to note the extensive media reports mentioning a "sector under pressure" while there have been no improvements in job conditions or wages. It is actually complex to say the least to determine the reality of difficulties in hiring (ESTRADE, 2013), particularly because many companies have "extensive" recruitment practices: for example, a large number of "permanent" advertisements are placed, which aim to attract applications for positions that will become open only if new clients come forward. Interviews with employers often underline both the importance of the flow of applications ${ }^{6}$ and the difficulty in retaining these employees. The possible pressure on hiring is thus not due to a quantitative weakness in the labour supply but rather to a mismatch between employers' requirements and the quality of jobs on offer. To deal with this, employers and public policy aim not to improve the quality of employment (which is considered too costly), but rather to increase the potential recruitment pool as much as possible.

The low employment rate (rather than the high unemployment rate) is then highlighted (ZAJDELA, 2009), especially in the case of young people under age 25, immigrant women and mothers. Specific measures are taken to encourage these categories to join the labour market. These measures may aim to reduce real or assumed obstacles preventing the expression of a labour offer by providing assistance with mobility (aid for obtaining a driving licence, for example) or developing more customised employment contracts (student contracts, voluntary part-time contracts, etc.). Recruitment methods could also be adapted, both in terms of selection criteria (with emphasis on specific socio-demographic characteristics) and in terms of networking (forums, "speed dating", permanent advertisements, etc. ${ }^{7}$ ). The role of labour market intermediaries is also central here: France's job centres (Pôle emploi), local agencies, social services, etc., are directly involved in constructing a flow of female jobseekers into these professions. Speaking more analytically, we can see that the existence of a de-skilled workforce (i.e. whose qualifications have been eroded - or at least employers believe this to be so - in particular following a suspension of professional activity), e.g. "mothers returning to work", has been reinforced by public measures such as parental leave, which have had impacts on women's qualifications and careers and been extensively highlighted (MÉDA, PÉRIVIER, 2007).

6. "We get CVs every day. Every day, women come by the agency. Every single day". (Employer, SAP Company, 2018)

7. In the case of our study on outsourcing the maintenance of nineteen secondary schools, for example, two employees of the service provider explained that they were recruited "in five minutes, right at the gate". The area manager who hired them confirmed that "in this [geographical] sector and given the unemployment rate, it is not difficult to find people" (Area manager, man, 2015 [Devetter, Steinauer, 2017]). 
This situation is directly observable in the personal services sector. Indeed, labour market intermediaries, notably Pôle emploi and the employment services of France's départemental councils, are directly encouraged to orient female job seekers towards these professions (AlBEROLA et al., 2011). One home help we met confirmed this almost systematic orientation towards personal services:

"When I needed to work for a salary, the only thing I was offered was to work with the elderly. I didn't hesitate for long really, I didn't have a choice."

(Home help, woman, 2016 [DEVETTER et al., 2016])

Employers, like public agencies, also seek to attract certain segments of the workforce by emphasising the "natural" skills that are needed but also by announcing that they take into account the specific constraints on "mothers". The $\mathrm{O} 2$ company thus publishes testimonials from employees on its recruitment page, all of which emphasise the compatibility of their working hours with family constraints. The selection of personnel can take complex paths, such as the segmentation of profiles based on the supply of specific work schedules. Some employers explicitly propose jobs with very limited schedules offering the supplement of a small wage but compatible with family responsibilities, as the following discussion illustrates:

"The second profile? The mother who has sacrificed her career to raise her children and who wants a supplemental income and work schedules consistent with her obligations (no Wednesdays, etc.). They work twenty hours a week. Everyone is happy."

(Company head, male, 2008 [Devetter, Rousseau, 2009])

The immigrant population (women in particular) is a second category of labour that is steered towards personal services. While labour import policies have been studied in the case of industrial and construction jobs (JounIN, 2009), there have been fewer studies of low-skilled service jobs. However, there has been a long tradition, visible in domestic services, of recurrent recourse to allogeneic labour: coming from Brittany and Belgium in the early 20th century, the West Indies in the 1930s, Spain and then Portugal in the 1960s and 1970s, etc. (Martin-Huan, 1997). Public policy has recently relaunched this process, symbolised by an agreement in 2008 between France's National agency for personal services (Agence nationale des services à la personne, ANSP) and the Ministry of Immigration, aimed at making it a priority to orient new arrivals to these services (DEVETTER et al., 2015). Similarly, a report by the Centre D'ANAlYSE STRATÉGIQUe entitled Besoins de main-d'œeuvre et politique migratoire ["Labour Needs and Migration Policy"] (May 2006, p. 53) states that it is in the health care and personal services and home help professions "that recourse, at least temporarily, to greater immigration can be justified". On the side of employers and employer associations, the strategies are fairly explicit when recruitment is based on "ethnic" networks (ANDERSON, 2000; BAKAN, STASILIUS, 2005; IBOs, 2013; APRIL, 2014). The priority hiring of immigrant women employees also takes place through other forms of the naturalisation of skills; in an interview in 2009, a member of one employer association emphasised "the love of elderly people for African women". 
Here, naturalisation is to be understood as a social process that treats skills or qualities as innate, thereby denying that they are the result of a process of socialisation rooted in social relations structured by gender and origin (DUSSUET, 2010).

For example, in order to avoid having to compete in the labour market, employers in the personal services sector (as well as in cleaning and catering) seek to exploit "underutilised" segments of the workforce. In this sense, they can play a role of integrating into employment categories of employees who traditionally have less job access while doing this at particularly low job quality levels.

In addition to the personal services sector, the other occupations found in degraded service jobs are also affected by these types of mechanisms. The most significant case probably concerns employees in the hotel and catering industry, where "specific categories" (immigrants and students in particular) play a central role. As Pierre BARRON and his co-authors (2011) point out, quoting André Daguin, head of the Union des métiers de l'industrie hôtelière (hotel workers union), the recruitment of undocumented employees seems to be "an economic necessity". Similarly, far from being a supplemental workforce, young students make up a significant proportion of employees and contribute to maintaining an undemanding labour supply (NKOUATCHET, 2005).

\section{Making Work Pay}

Developing an available labour force not only involves recourse to "new" populations, but also requires convincing employees to accept the jobs in question. Once again, both public policy ${ }^{8}$ and employers contribute in general to this objective, either by seeking to "make work pay" (i.e. more remunerative and profitable for the individual) or by reducing the ability of future employees to refuse unattractive jobs (CATTACIN et al., 2002; FAGAN et al., 2006).

The conversion of France's minimum income benefit (Revenu minimum d'insertion, RMI) into an in-work income supplement (Revenu de solidarité active, RSA), which is designed to facilitate the partial accumulation of job income and social assistance, is probably the most important example of a public measure that follows this "workfare" logic. The public policy in favour of personal services thus emphasised the need to make use of the RSA supplement for this purpose, ${ }^{9}$ and France's National Agency for Personal Services (ANSP), like the business world, ${ }^{10}$ broadly publicised the possibility of relying on this system. The ANSP website provided clear information about how

\footnotetext{
8. Public aid as presented in this paragraph primarily concerns direct subsidies for the labour supply, but it can also take the form of demand subsidies that lower the "cost" of labour while indirectly supporting the net wage paid to employees. 9. Thus, according to Michèle Debonneuil (2008, p. 31), the RSA income supplement should be encouraged "so that companies have less difficulty finding candidates, since they could offer anyone seeking full-time work to be paid as if they were working full-time even though they would be working part-time".

10. To take one example among many, see the press release "Adecco à domicile et l'Afpa forment des bénéficiaires du RSA" ["Adecco at home and Afpa train RSA beneficiaries"]: http://www.groupe-adecco.fr/articles/adecco-a-domicileet-lafpa-forment-des-beneficiaires-du-rsa, accessed 1st February 2021.
} 
employees could benefit from the RSA ${ }^{11}$ and ended with the slogan "That's what the RSA is for!". The agency also had an information brochure on the RSA supplement sent out to all employees being paid with universal service employment vouchers (Chèques emploi service universel, CESU).

Measures aimed at encouraging a so-called "reasonable" job offer or seeking to make social assistance conditional on a "job" offer are extending this logic in France and more generally throughout Europe. Unskilled jobs in fields akin to personal services thus constitute a large contingent of Germany's mini-jobs (HIPP et al., 2015). Similarly, the numerous subsidies and social and tax exemptions enjoyed by low-skilled jobs and, even more so, the personal services sector, are enhancing the possibility of paying for work that is considered not to be worth what it costs (i.e. where perceived productivity is considered to be lower than the wage paid) (DEVETTER, JANY-CATRICE, 2010).

At the employer level, this logic involves recruitment strategies that specifically target "low employability" employees in other segments of the labour market. For example, one employer (DEVETTER, Rousseau, 2009) insisted in 2008 on recruitment criteria that would avoid an excessive turnover rate: "Young girls don't come to us to stay. It's a temporary job. But for 40-year-old women, they don't see themselves doing anything else."

The fact that employees have gone through a "difficult period" may also be an important criterion:

"We're in a disaster area for textiles. There are a lot of people who come from this sector, who are between 35 and 50 years old. It's where we have the easiest time recruiting because they are professional and have respect for the customer and respect for the employer that is more extensive than younger people do."

(Company head, 2008 [Devetter, Rousseau, 2009])

These selection methods may explain the apparent paradox between the very low employability of employees according to traditional criteria (qualifications, mobility, etc.) and how easy it is for them to get hired: it is precisely these usually negative criteria that are sought here by some employers (DEVETTER, ROusSEAU, 2009). Employers thus sometimes explain that they distinguish between "vehicled" and "non-vehicled" employees and, if concretely possible, favour the latter. The sometimes negative impact of holding the DEAVS diploma described in the previous section indirectly stems from this same process of indifferentiation that nourishes an abundant supply. Thus, the low employability of female employees is to be understood not as leading to difficulties in being hired, but as characteristics in terms of low geographical and professional mobility in particular which lead to degraded positions on the labour market.

11. The ANSP page, "Bénéficiez du RSA!" [“Benefit from the RSA!']: https://archives.entreprises.gouv.fr/2013/www. servicesalapersonne.gouv.fr/beneficiez-du-rsa-pour-ameliorer-votre-quotidien-(12164)d41d.html, formerly online, accessed 5 December 2018. 
Outside the field of personal services, the use of subsidised contracts can also exemplify this strategy, which is aimed at both making work pay (by supplementing the salary with social assistance) and making it difficult to refuse, as jobs are offered by the social services. The case of local authority agents (including, since 2005, those in schools) is emblematic. In the context of producing monographs covering nineteen secondary schools (DeVeTter, Steinauer, 2017), it turned out that the additional manpower provided by employees on subsidised contracts was not at all an extra cost but rather a means of supplementing teams that were clearly inadequate. According to the Working Conditions survey, subsidised jobs represent more than $12 \%$ of service positions in schools (profession 525A).

\section{Segmentation and Division of Labour}

Finally, a third mechanism can block or reverse the process of constructing a path to professionalisation and higher pay: the maintenance of a division of labour that hinders the possibilities of forming a homogeneous work collective and limits the impact of trade union demands. Two processes involved in the division of labour can be identified here: the recourse to a wide variety of types of employers and statuses (to perform the same job) or competition between different jobs (to perform the same tasks), on the one hand, and measures that make it difficult to structure a work collective, on the other. Yet again, each of these two processes is backed up by public policy and by HR policies developed by employers.

\section{Competition between Different Types of Employers, Professions, and Collective Agreements}

Of the ten occupations at the bottom of the wage hierarchy, almost all are subject to multiple modes of organisation, which put different types of employers in competition with each other: the coexistence of national guidelines and national collective agreements (NCAs) or specific forms of employment ("extra" and very short fixed-term contracts in the restaurant industry, outsourcing and subcontracting in the hotel and cleaning industries, etc.). The coexistence of public bodies, associations and private firms, or even direct employment by an individual employer to organise comparable work does not occur very frequently from a general point of view, but it is common for domestic workers, home helps, childcare assistants, and cleaning personnel. Likewise, several of these occupations are among those most exposed to the growth of subcontracting. Female cleaners and chambermaids are particularly exposed to outsourcing: $60 \%$ of female cleaners work in the cleaning sector, while the others are employed by companies that keep their cleaning staff in-house but come from different economic branches. However, the use of subcontracting is leading to a net deterioration 
in job conditions for employees, both in France (ABASABANYE et al., 2016; DeVETTER, Steinauer, 2018) and abroad (Holley, RainNie, 2012; Grimshaw et al., 2014).

The personal services sector is emblematic of this fragmentation between different types of employers and job terms and conditions, a fragmentation that leads to great heterogeneity in the applicable rules (particularly those stemming from NCAs). Far from seeking to unify the sector, public policy has promoted the diversification of these employment arrangements since the 1980s, from the very first incentives for the development of direct employment. Then incentives in favour of lucrative businesses were strengthened in the 1990s, but with a clear acceleration in 2005 with France's personal services development plan. This accentuated competition between types of employers, with differences in their status having strong repercussions in terms of working and employment conditions (LEFEBVRE, 2012; DEVETTER et al., 2017).

The fostering of competition between different types of employers is also due to their own actions, whether at the level of the branches or the enterprises themselves. The plurality of collective bargaining agreements, ${ }^{12}$ which is characteristic of the home help industry, is a determining factor in price competition between different types of employers and service providers. It also contributes to fragmentation and to weakening the representation of the personnel, especially as the trade union leaders struggle to standardise their methods of representation: the negotiators for the different branches usually belong to separate unions ("social health care"13 for the home help branch and "commercial services" " for for-profit personal services firms). Strengthening competition is also part of the strategy of the enterprises themselves, through the multiplication of agencies or employing units, which makes it possible, consciously or not, to circumvent the thresholds for staff representation and to optimise certain tax schemes (PERRAUDin et al., 2006). The use of franchising by for-profit firms and the splintering of associations into small local structures are blatant examples of this. Another example of an employer strategy that exacerbates competition between these different types of services is the use of two systems of employment: service provision and contracting (diagram). The service providers are collective organisations that can have different statuses (public or private, for-profit or not-for-profit): they employ home helps, pay them and determine their schedules, etc. The employees work in the homes of users who finance a help service, but do not employ them or pay them directly. In this case, the employees are subject to the collective agreement corresponding to the status of their employer (the 2013 NCA for a for-profit personal service provider, or the 2010 NCA for a service provider association). However, many of these organisations are developing a so-called intermediary service within their organisation, alongside their service provider activity. In this case, the provider does not employ the employees: it

12. Coverage by a collective agreement depends on the legal status of the employer and not on the activities performed. 13. This is more specifically the Fédération des organismes sociaux for the CGT trade union (Confédération générale du travail) and the Fédération « santé sociaux » for the CFDT trade union (Confédération française démocratique du travail).

14. This is the Fédération du commerce for the CGT and the Fédération des services for the CFDT. 
is the users who directly employ and pay them, mainly in the form of the CESU credit vouchers. The employees are therefore subject to the collective agreement governing the individual employer. The intermediary organisation is paid by the users only to help them with the administrative management of employment (drawing up pay slips, holidays, sick leave, etc.) and in the planning of schedules in the event of absence, for example, to provide a temporary replacement. Often in the course of a single day employees will be required to work under several collective agreements, sometimes with the very same users.

DiAgRAM - The Different Modes of Employment in Personal Services

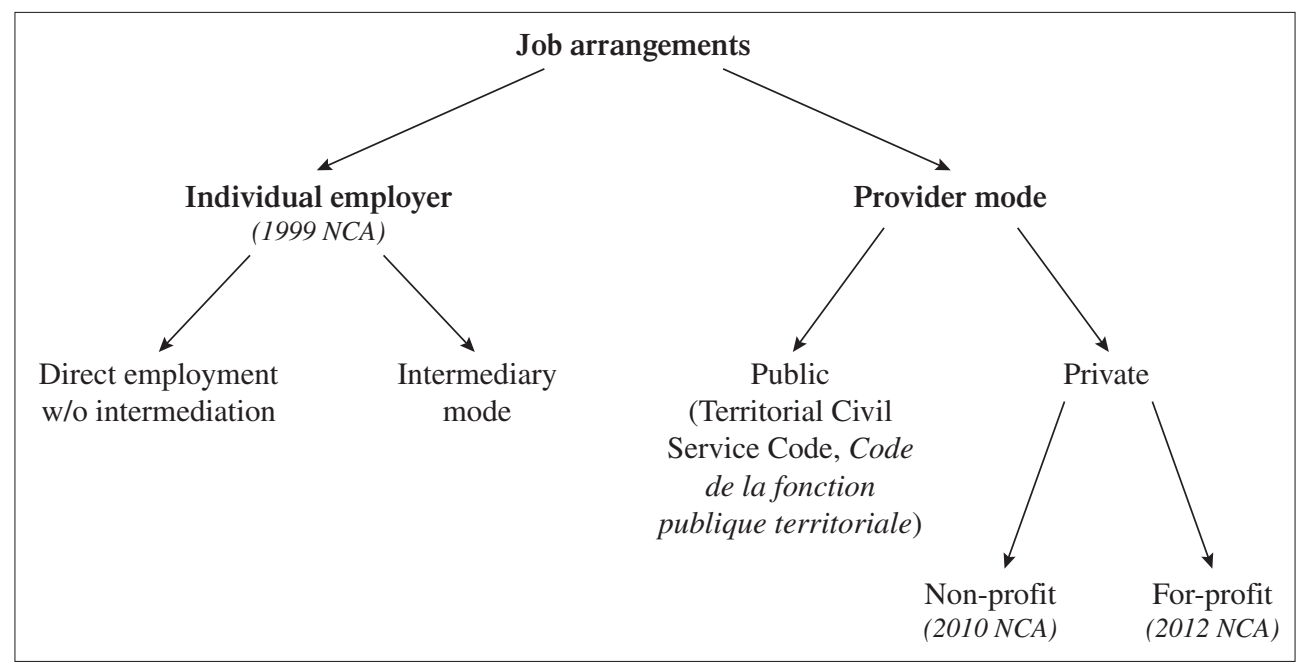

Source: Authors.

This situation is a major obstacle to trade union representation, as attested by an excerpt from an interview conducted in 2012 with the leader of the Rhône-Alpes regional CGT trade union for "home help" (LAMOtTE, Puissant, 2013):

"Personal services are a real trade union challenge! Unions need to talk to each other, girls don't necessarily see themselves involved in social action [sic], but more in health care. And the associations are often so small, the girls are isolated. We're considering the creation of an economic and social union, so that employers are obliged to group together, and we can then create unions in the associations. We are also thinking about creating local unions for all the home helps who would like to join a union. Trade unionism must evolve to respond to these changes, and to allow these girls to join a union and defend themselves, but it's not easy."

Competition between types of employers may be reinforced by a division between occupations originally conceived as distinct. Thus, historically, it is the activities furthest removed from household chores, carried out by home helps, that have been recognised as requiring special skills. The first diploma in the sector dates back to the 1950s, and concerned home help to families involving so-called educational activities 
with children. Recognition came later for services for the elderly (1990s) and was for work involving "assistance with activities of daily living" (branch agreement of 29 March 2002 on job classifications), i.e. assistance to the person and not to the home (assistance with mobility, washing, meals, etc.). Professional recognition thus operates in a fragmented way: recognising the work and skills of certain people (personal assistance, i.e. help with educational activities with children, and help with so-called activities of daily living, according to the terms used in the collective agreement of the home help branch, i.e. help with washing, mobility, meals, etc., for elderly or disabled people) amounts implicitly to not recognising the work of others (ARBORIO, 2012). Professional recognition takes place through the objectification of only those tasks that fall within the scope of social and medico-social action standards (which concern personal assistance). Thus, for employees who do not perform this type of task for individuals, but who mainly perform tasks of assistance with maintaining the home (help with housekeeping, ironing), the levers for professional recognition do not exist. This division is based on the idea that carrying out activities, even mainly housework, for vulnerable groups does not require any particular professional skills, since no diploma exists in this area. It is not difficult to imagine another process, focusing on the users: intervening with fragile users requires specific professional skills and therefore qualifications, since household tasks are first and foremost supports for a more complex relationship and not an end in themselves (JANY-CATRICE, 2010). This tension can be found in the representation of occupations in the following interview excerpt:

"Often people's families take us for cleaning ladies. The people we're helping know and see that we are more, that we are there for them, and not simply for housekeeping. But it's not the same thing with the families. They're not present often, and think of us as cleaning ladies. But we are there for their parents, so when they're depressed, it's us they talk to. Sometimes the grannies even prefer to talk to me than to their daughters, they feel freer, I don't know..."

(Home help, 2012 [LAMotTe, Powerful, 2013])

This division of professional recognition may be reinforced by the organisation of work in certain entities; in this case, this generates strong competition between employees. The fact that skills are recognised and formalised in the context of a diploma, while this diploma is not a barrier to entry into the sector, has led to differentiated qualifications for home helps. ${ }^{15}$ Today the only way to make the transition to the skilled category is no longer through seniority, but by earning a State diploma. Although the DEAVS diploma is available for the validation of acquired experience (it was the first diploma, in 2002, to be available under the VAE programme), we have

15. The 2012 collective agreement for the home help branch (private non-profit sector) picks up from the branch agreement of 29 March 2002, which defined four categories of home helps: 1) A: home help, no qualification, 2) B: home help, in the process of validation of prior learning or a technical diploma (Brevet d'études professionnelles, BEP - Brevet de technicien supérieur, BTS), 3) C: homecare assistant: holder of the State diploma of a homecare assistant - which no longer exists since 1 January 2016, and 4) D: technical agent for social and family intervention for assistance to children in families in difficulty. 
shown in previous work (PUISSANT, 2010) that in a sector made up of women who have often had a complicated relationship with school and studies, the fact of committing to a VAE approach proves to be problematic for many. Formalising a professional practice can be a difficult exercise for many home helps, which explains why a large proportion of them self-censor by refusing to engage in a VAE process, or by not validating all the modules. Thus, a home help with more than twenty years of seniority, but without an official qualification, will be in category A - unqualified. Some employees sometimes speak of "betrayal", interpreting this categorisation as a way of not recognising the work they have been doing for a long time, and for which they have sometimes taken training modules.

"I've been doing this job for more than fifteen years. I know that I know my job, I'm not going to go get a diploma. They're not the ones who are going to decide whether I know my job. All they have to do is go and see the people I'm going to, they're happy. I know that I know my job. And when the girls graduate, they feel they've moved up, they don't want to empty the rubbish bins anymore! As if it was me who had to empty the rubbish bins every time!"

(Home help, 2016 [DevetTER et al., 2016])

The resentment is all the more acute as the categorisation of home helps does not lead to concrete differences in the work that each of them does. In fact, employers lack qualified workers to accompany ageing and the increasing incidences of disability: unqualified employees therefore continue to work in the homes of dependent users, as shown in the following extract.

"On weekends, we intervene only in the homes of people who are very dependent. So, if I'm only supposed to do housework, why do I work all the time on weekends?

So now they don't mind that I don't have a diploma and that I'm paid the minimum wage to help with their toilet!"

(Home help, 2016 [DevetTER et al., 2016])

This kind of slippage in tasks and competition between professions sharing a workspace is not specific to personal services, and comparable phenomena can be observed in social and medico-social housing (NIRELLO, 2015), and even in hospitals (ARBORIO, 2012).

These forms of fragmentation are also increasingly found in public services, such as maintenance jobs in secondary schools. An analysis of the organisation of maintenance work in nineteen secondary schools in a département that is experimenting with the use of subcontracted staff (DEVETTER, STEINAUER, 2017), highlights the fact that in these establishments the cleaning activities are carried out by employees with four different statuses: the most stable are civil servants in the local civil service; next come contract workers hired for periods of ten-and-a-half months; then employees on subsidised contracts; and finally cleaning staff employed by a service provider. These four forms of employment are assigned to broadly comparable tasks, although the personnel concerned have neither the same resources (training, experience, occupational 
integration, equipment, etc.) nor the same job conditions and wages. Monthly pay can thus vary by as much as twice, depending on the employee status (with pay scales that are more or less advantageous), but above all depending on the working time allocated to clean a given area (from forty-one hours to twenty hours per week for equivalent areas). This example shows that the existence of a plurality of statuses for carrying out the same activity (dividing and weakening the employees' negotiating capacities) is not specific to personal services alone.

The people in these service professions thus share the characteristic that they are divided between a wide variety of statuses and occupations, yet are called on to perform the same tasks and fulfil the same missions.

\section{The Weakening of Work Collectives}

In addition to this "statutory" division, the organisation of work is often fragmented, which tends to isolate employees and block the emergence of work collectives. This situation is mainly found at the level of employment agencies, but also arises because of unfavourable public regulations.

Indeed, the low-skilled service professions have been significantly influenced by the flexibilisation policies that have been implemented over the last twenty years: the facilitation of part-time work, the development of flexi-time, the increase in selfemployment, etc. These measures are not aimed specifically at low-skilled service jobs, but they have been particularly widespread in this type of employment: for example, there are significant numbers of self-employed entrepreneurs in personal services (ThIÉRUs, 2014), the cleaning sector (DENIS, 2018), and delivery services.

In personal services, the characteristics of the activity and the fact that it takes place in the home of the beneficiaries "naturally" tend to isolate the women workers. However, forms of organisation that counteract this isolation, such as the triangular model - user/employee/association - invented within the associative framework (PUISSANT, 2010), have made it possible to create collective work spaces, which are essential for the constitution of a professional group (ARTOIS, 2015). However, this triangular organisation (where an employer structure is inserted between the user and the employee) has been increasingly challenged since the 1990s, and especially since the early 2000s. Public policy has strongly encouraged this challenge, first through incentives in favour of direct employment, and then by favouring for-profit "service providers" whose sole role is to arrange the employment relationship (with the employer's function reduced to the legal dimension alone). The creation of a personal services market in 2005 further weakened the service provider mode, by encouraging competition and putting pressure on costs. Although the Borloo plan initially encouraged the rapid growth of for-profit service providers through various tax and social security exemptions, this momentum was then curbed. A study by a consulting firm warned as early as 2010 about the closure of private for-profit companies which, 
without major exemptions, were running large losses as soon as they set up outside the major metropolises (BELZE, 2011).

Several studies (VATAN, 2014; Le Roy, Puissant, 2016) have since drawn attention to the fact that the reference economic model implicitly followed by the public authorities (or départemental councils for the care of the elderly), particularly in terms of pricing, corresponded to the situation of direct employment. Several départemental councils thus use the "productive" working time indicator to establish their rates and the working time they are prepared to finance out of public funds. However, this socalled productive time does not take into account working time spent outside the home, even when it is part of the service provided there (PUISSANT, 2010; LEFEBVRE, 2012; Dussuet, 2013). As a result, the total time that constitutes one of the specific features of the service provider model tends to be sharply reduced, and is no longer funded. A collective system, with positions for coordination and middle management, training time, meeting time, the right of expression, etc., is inevitably more costly than direct employment, where only activities that take place in people's private homes are taken into account. This competition is increasingly encouraging local authorities to include in the hourly rates they set with the agencies only so-called "productive" hours (i.e. the hours of intervention in the home, which represent around $80 \%$ of the overall volume of work in the service provider entities; AUBE-MARTIN et al., 2010).

These developments are affecting HR policies and the organisation of work: the rationalisation observed since the mid-2000s in the associations is accelerating and spreading to the entire service provider mode. This can be seen first of all in the tendency to question "usages" in the agencies, i.e. the gains resulting from local negotiations, which represent informal improvements to what is provided for in the collective bargaining agreements and branch agreements (break times, recognition of travel time exceeding a quarter of an hour, recovery days, end-of-year bonuses, etc.). This then translates into the calling into question of collective work spaces: the reduction of coordination positions (their number and prerogatives), of time for exchanges with colleagues, and of collective working time. Finally, this is being accompanied by the generalisation of control tools, such as remote management, which contribute to increasing work rates and de-skilling work:

"With remote supervision, our capacity for judgment is no longer recognised! While we used to think that we might need to stay fifteen minutes longer than we were supposed to in a person's home, well, now we can't, we're controlled!"

(Home help, 2016 [DevetTer et al., 2016])

These strategies are sometimes found very explicitly in HR policies, which aim to maintain the isolation of employees more or less deliberately:

"No gatherings. I'm all for keeping them separate. This is the voice of experience speaking, about everything to do with labour unions, works councils, and all that. The more people are separated, the less they talk, the less they criticise the boss or 
management. I continue to make sure that they are split up and come together as little as possible."

(Company head, 2008 [DevetTer, Rousseau, 2009])

Once again, these mechanisms, summarised in Table 2, can be seen, beyond personal services, in most degraded service jobs. We have already mentioned the case of multi-skilled maintenance workers, who are divided among several statuses (DEVETTER, STEINAUER, 2017). These workers are also often the subject of work organisation measures designed to avoid the emergence of work collectives: in the context of outsourcing their activity, the départemental council explicitly requires separate premises (for breaks and storing equipment) for private and public sector employees; the organisation of this subcontracting deliberately establishes two distinct categories of personnel, who are invited to think of themselves as being opposed to each other, with a clearly defined "them" and "us".

\section{TABLE 2 - Synthesis of the Mechanisms of Non-Recognition of Qualifications in Home Help Services}

\begin{tabular}{|c|c|c|c|}
\hline \multirow{2}{*}{\multicolumn{2}{|c|}{$\begin{array}{c}\text { Mechanisms of non-recognition } \\
\text { of qualifications }\end{array}$}} & \multicolumn{2}{|c|}{ Level of decision and implementation } \\
\hline & & Public Policy & Human Resources Policies \\
\hline \multirow{2}{*}{$\begin{array}{l}\text { Denial of the } \\
\text { qualities used }\end{array}$} & $\begin{array}{l}\text { Naturalisation of skills and } \\
\text { absence of "entry barriers" }\end{array}$ & $\begin{array}{l}\text { Late and ambivalent } \\
\text { recognition of qualifications }\end{array}$ & $\begin{array}{l}\text { Recruitment criteria outside the } \\
\text { professional sphere and non- } \\
\text { degree courses }\end{array}$ \\
\hline & Euphemisation of hardships & $\begin{array}{l}\text { Difficulty in taking into } \\
\text { account hardships; restrictive } \\
\text { calculation of pricing; absence } \\
\text { of prevention policy }\end{array}$ & $\begin{array}{l}\text { Relativisation of the issue of } \\
\text { working conditions; restrictive } \\
\text { calculation of working time }\end{array}$ \\
\hline \multirow[b]{2}{*}{$\begin{array}{l}\text { Construction } \\
\text { of excess } \\
\text { supply }\end{array}$} & $\begin{array}{l}\text { Putting "mothers", } \\
\text { immigrant women, to work }\end{array}$ & $\begin{array}{l}\text { Specific guidance by } \\
\text { employment intermediaries }\end{array}$ & $\begin{array}{l}\text { Employment of "moms"; } \\
\text { use of "ethnic" networks }\end{array}$ \\
\hline & $\begin{array}{l}\text { Making underpaid work } \\
\text { acceptable }\end{array}$ & $\begin{array}{l}\text { RSA and PPE (Prime pour } \\
\text { l'emploi) income supplement } \\
\text { benefits; workfare: "making } \\
\text { work pay" }\end{array}$ & $\begin{array}{l}\text { Selection of "unemployables" } \\
\text { or temporary employees }\end{array}$ \\
\hline \multirow{3}{*}{$\begin{array}{l}\text { Division of the } \\
\text { workforce }\end{array}$} & $\begin{array}{l}\text { Competition between } \\
\text { employers }\end{array}$ & $\begin{array}{l}\text { Encouragement of a plurality } \\
\text { of employers and wage } \\
\text { conditions }\end{array}$ & $\begin{array}{l}\text { Plurality of collective bargaining } \\
\text { agreements; multiplication of } \\
\text { agencies; use of intermediary } \\
\text { agencies }\end{array}$ \\
\hline & $\begin{array}{l}\text { Competition between } \\
\text { "professions" }\end{array}$ & $\begin{array}{l}\text { Division of professional } \\
\text { recognitions }\end{array}$ & $\begin{array}{l}\text { Work organisation that } \\
\text { exacerbates day-to-day } \\
\text { competition between skilled } \\
\text { and unskilled workers }\end{array}$ \\
\hline & $\begin{array}{l}\text { Weakening of work } \\
\text { collectives }\end{array}$ & $\begin{array}{l}\text { Direct employment; } \\
\text { competitive pressures; } \\
\text { restrictive pricing }\end{array}$ & $\begin{array}{l}\text { Calling into question collective } \\
\text { time; rationalisation in the } \\
\text { organisation of work; increases } \\
\text { in work pace }\end{array}$ \\
\hline
\end{tabular}

Source: Authors. 
While the ranks of female graduates from secondary and higher education continued to grow rapidly during the 1990s and 2000s, the trends in job qualifications have been more ambiguous: growth in highly qualified jobs (especially those with management status) but also a resumption in the creation of jobs considered as low-skilled or unskilled. Public policies aimed at reducing the cost of labour are not unrelated to this phenomenon (Gautié, Margolis, 2009; Jaehrling, Mehaut, 2013), but the role of public policy and employers' HR management strategies has gone well beyond mere economic support and has encouraged job polarisation, driven by the growth of jobs in degraded services at least as much as by the decline in industrial jobs with intermediate qualification levels.

Thus, several mutually reinforcing mechanisms have been involved in maintaining numerous service jobs in the "unskilled" categories: the denial of the qualities used and the hardships endured; the orientation of a fragile and "cheap" labour flow towards these segments; and strategies to divide the workforce that render it de facto impossible to take collective action or raise collective demands. Based on the analysis of these three mechanisms, which have repercussions in terms of both de-skilling and "invisibilisation", we have shown that the secondary segment of the labour market is not, as sometimes presented more or less explicitly in approaches to labour market segmentation (DoERINGER, PIORE, 1971; MARSDEN, 1999), an "unorganised" market or a form close to a market with pure and perfect competition. On the contrary, it is the result of a social and political construction.

While we have highlighted the fact that a number of mechanisms involving the non-recognition of skills and even the de-skilling of work also exist in other segments of so-called secondary employment, further progress can be made in understanding the dynamics of low-skilled or unskilled segments of service occupations. Indeed, the home help sector, and more generally the field of personal services, has a strong heuristic value for understanding the real barriers to qualification in major occupational segments in which women are over-represented. The facilitation of direct employment (and then the use of highly flexible service providers) and budgetary pressures on service provider jobs have undoubtedly contributed to a laboratory for the deregulation of the wage relationship, as is evidenced by the rapid spread of statuses that allow the expansion and diversification of work situations outside any collective work framework, particularly with regard to the development of digital employment platforms.

This development is reminiscent of the processes described and analysed in detail by radical American socio-economists in the field of industrial jobs (e.g. MARGLIN, 1974; BRAVERMAN, 1976; Gordon et al., 1982). The development of certain commercial services required the creation of a social category (female and precarious), just as industrialisation in the 19th and early 20th centuries was grounded in the creation of a low-cost working class.

There are nevertheless two important differences that distinguish the current situation from the period of industrialisation in the past centuries. The first concerns the trajectory followed, both individually and collectively: the entry into the labour market 
of female labour, which is considered low-skilled (DAUNE-RICHARD, 2003; DwYER, 2013), is also part of a dialectical process of a (partial) reduction of the exploitation of female labour by men within the context of patriarchal society (DELPHY, 2015). Thus, just as wage labour may initially appear to be a step forward from serfdom, so the female precariat could be viewed as a first step towards the recognition of the value of women's labour. The second difference concerns the interpretation in terms of long-term obstacles to the recognition of service occupations: the activities covered by the title "unskilled employee" are generally relational and consist of social interactions where the difference between work and service is minimal, unlike in industry where the machine and the organisation of labour are important mediators between the consumer and the employee. This relational aspect has a greater impact on the quality of the result than on its "volume". It is more difficult to identify the existence of productivity gains (in the industrial sense of the term), and the meagreness of these gains "to be shared" consequently makes the conflict more bitter and reinforces the import, for those who benefit from them, of seeing to it that the quality - and therefore the skill - of the services rendered and the work performed is not recognised. The construction of a social compromise in these relational services can thus be achieved only through the growth of a "willingness to pay" expressed by consumers and even more so by the broader community.

\section{REFERENCES:}

AballÉA, F. (2005). «La professionnalisation inachevée des assistantes maternelles. » Recherches et prévisions, 80, 55-65.

Abasabanye, P., Bailly, F., and Devetter F.-X. (2016). "Does Contact Between Employees and Service Recipients Lead to Socially More Responsible Behaviours? The Case of Cleaning." Journal of Business Ethics, (153)3, 13-824.

Aboubadra, S., Argouarc'h, J., Bessière, S., Colin, J.-F., Jolly, C., and Lainé F. (2014). Les Métiers en 2022. Résultats et enseignements, Rapport du groupe Prospective des métiers et qualifications. Paris: Dares, France stratégie.

Alberola, E., Gilles, L., Tith, F. (2011). « Les services à la personne: un levier d'insertion pour les publics éloignés de l'emploi ? » Cahier de recherche, no 288, Crédoc.

Amossé, T., Chardon, O. (2006). «Les travailleurs non qualifiés: une nouvelle classe sociale ?» Économie et statistique, 393-394, 203-229.

Anderson, B. (2000). Doing the Dirty Work? The Global Politics of Domestic Labour. New York: Zed Books.

ARBORIO, A.-M. (2012). Un personnel invisible. Les aides-soignantes à l'hôpital, $2^{\text {nd }}$ ed. With a preface by the author. Paris: Économica, Anthropos. 
Artois, P. (2015). La Pluralité des modalités de professionnalisation contemporaines: le groupe professionnel des aides familiales au cour de tensions. (Thèse de doctorat en sociologie, Bruxelles, Université libre de Bruxelles).

Ast, D. (2015). «En 30 ans, forte progression de l'emploi dans les métiers qualifiés et dans certains métiers peu qualifiés de services. »Dares analyses, no 028.

Aube-Martin, P., Bruant-Buisson, A., and Reboul J.-B. (DE) (2010). Mission relative aux questions de tarification et de solvabilisation des services d'aide à domicile en direction des publics fragiles, Rapport. Paris: Inspection générale des finances, Inspection générale des affaires sociales.

Avril, C. (2014). Les Aides à domicile. Un autre monde populaire. Paris: La Dispute.

BaKan, A. B., Stasilius, D. K. (2005). Negotiating Citizenship: Migrant Women in Canada and the Global System. Toronto: University of Toronto Press.

BArron, P., Bory, A., and Tourette L. (2011). On bosse ici, on reste ici ! La grève des sanspapiers: une aventure inédite. Paris: La Découverte.

Belze, C. (2011). Cartographie problématisée de l'aide à domicile en région Rhône-Alpes, Report of Sécafi, ordered and financed by the CGT Rhône-Alpes, in the course of the researchaction programme "Sécurisation des parcours professionnels".

Blanchet, D., Ravalet, P. (1995). «Transferts, salaire minimum et services de proximité : une maquette théorique. » Revиe économique, (46)3, 573-583.

Braverman, H. (1976). Travail et capitalisme monopoliste. La dégradation du travail au $X X^{e}$ siècle. Paris: F. Maspero.

Budig, M., England, P., and Folbre, N. (2002). "Wages of Virtue: The Relative Pay of Care Work." Social Problems, (49)4, 455-473.

Burnod, G., Chenu, A. (2001). «Employés qualifiés et non qualifiés : une proposition d'aménagement de la nomenclature des catégories socioprofessionnelles. » Travail et Emploi, $86,87-105$.

CAHuc, P. (2001). « Pourquoi y a-t-il des différences de salaires ? Reflets et perspectives de la vie économique, (40)1-2, 13-24.

CAROli, È., Gautié, J. (2009). Bas salaires et qualité de l'emploi : l'exception française? Paris: Éditions Rue d'Ulm.

CArré, F., Tilly, C. (2012). "A Framework for International Comparative Analysis of the Determinants of Job Quality.” In C. Warhurst, F. Carré, P. Findlay, and C. Tilly (Eds.), Are Bad Jobs Inevitable? Trends, Determinants and Responses to Job Quality in the Twenty-First Century (pp. 12-183). Houndmills: Palgrave Macmillan.

Castel, R. (1995). Les Métamorphoses de la question sociale. Une chronique du salariat. Paris: Fayard.

Cattacin, S., Gianni, M., Mänz, M. et al. (2002). Retour au travail! Le workfare comme instrument de réforme. Fribourg: Éditions universitaires. 
Centre D’analyse stratégique (2006). Besoins de main-d'œuvre et politique migratoire, Rapport. Paris: Centre d'analyse stratégique.

CAISSE NATIONALE dE L'ASSURANCE MALAdIE DES TRAVAILlEURS SALARIÉs (CNAMTS) (2017). Synthèse de la sinistralité AT-MP 2016 tous CTN. Focus sur le périmètre du CTN D. Services, commerces et industries de l'alimentation. CNAMTS, Direction des risques professionnels [online]: http://www.risquesprofessionnels.ameli.fr/fileadmin/user_upload/document_PDF_a_ telecharger/etudes_statistiques/livret_de_sinistralite/2016/Livret\%20Sinistralit\%C3\%A9\%20 ATMP\%20CTN\%20D\%202016\%20(2017-133-D).pdf, accessed 1 February 2021.

CRESSON, G. (2006). « La production familiale de soins et de santé. La prise en compte tardive et inachevée d'une participation essentielle. » Recherches familiales, 3, 6-15.

Cresson, G. (dir.), Delforge, S., Devetter, F.-X., and Lemaire, D. (2011). Qualité du travail, qualité des emplois et qualité d'accueil dans les métiers de la petite enfance, Report of research for the Caisse nationale des allocations familiales, Centre lillois d'études et de recherches sociologiques et économiques.

DAUne-Richard, A.-M. (2003). « La qualification dans la sociologie française: en quête des femmes. » In J. Laufer, C. Marry, and M. Maruani (Eds.), Le Travail du genre. Les sciences sociales du travail à l'épreuve des différences de sexe (pp. 138-150). Paris: La Découverte, Mage.

Debonneuil, M. (2008). Les Services à la personne: bilan et perspectives, Orientation document. Paris: Inspection générale des finances.

Delphy, C. (2015). Pour une théorie générale de l'exploitation: des différentes formes d'extorsion de travail aujourd'hui. Paris: Éditions Syllepse.

DENIS, J.-M. (2018). « Asseoir la représentation sur la communauté de travail. À la recherche de la communauté perdue dans la branche de la propreté. » Sociologie du travail [online], (60)1: https://doi.org/10.4000/sdt.1748.

Devetter, F.-X. (Ed.), Abasabanye, P., Bailly, F., Barrois, A., Brolis, O., Chapelle, K., Dussuet, A., Léné, A., Nirello, L., Puissant, E., and Prouteau, L. (2016). La Qualité des emplois dans la crise : comparaison des secteurs public, privé et associatif, Report for DARES.

Devetter, F.-X., Dussuet, A., and Puissant, E. (2017). « Pourquoi les aides à domicile sontelles davantage rémunérées dans certains départements? » Revue d'économie régionale et urbaine, 2, 239-270.

Devetter, F.-X., Jany-CATRice, F. (2010). «L'invention d'un secteur et ses conséquences socio-économiques : les politiques de soutien aux services à la personne. » Politiques et management public, (27)2, 75-101.

Devetter, F.-X., Jany-Catrice, F., and Ribault, T. (2015). Les Services à la personne, nouvelle éd.. Paris: La Découverte.

Devetter, F.-X., Messaoudi, D. (2013). « Les aides à domicile entre flexibilité et incomplétude du rapport salarial: conséquences sur le temps de travail et les conditions d'emploi. » Revue de l'Ires, 78, 51-76. 
Devetter, F.-X., Rousseau, S. (2009). « Comment concilier service relationnel et marges réduites ? Le cas du secteur du ménage à domicile. » Gestion 2000, 2, 193-209.

Devetter, F.-X., Steinauer, O. (2017). L'Expérimentation de l'externalisation de l'entretien des collèges, Report for the départemental council of the Nord.

Devetter, F.-X., Steinauer, O. (2018). Le Travail des aides à domicile: prescriptions et temporalités, Working document. Lille: Clersé.

DoERINGer, P. B., PIORE, M. J. (1971). Internal Labor Market and Manpower Analysis. Heath: Lexington Books.

Dussuet, A. (1997). Logiques domestiques. Essai sur les représentations du travail domestique chez les femmes actives de milieu populaire. Paris: L'Harmattan.

Dussuet, A. (2005). Travaux de femmes. Enquêtes sur les services à domicile. Paris: L'Harmattan.

Dussuet, A. (2010). Femmes et services: entre public et privé. (Mémoire original pour l'habilitation à diriger des recherches, Tours, Université François Rabelais).

Dussuet, A. (2013). « Santé au travail et prévention des risques professionnels dans les associations d'aide à domicile. » Revue de l'Ires, 78, 77-97.

Dussuet, A., Nirello, L., and Puissant, E. (2017). « De la restriction des budgets des politiques sociales à la dégradation des conditions de travail dans le secteur médico-social. » Revue de l'Ires, 91-92, 185-211.

Dussuet, A., Puissant, E. (2015). « Un rôle ambivalent des associations dans la reconnaissance du travail salarié. L'exemple de l'aide à domicile. » Économies et sociétés, série « Socioéconomie du travail », 37, 991-1018.

Dwyer, R. E. (2013). "The Care Economy? Gender, Economic Restructuring, and Job Polarization in the U.S. Labor Market.” American Sociological Review, (78)3, 90-416.

ESTRADE, M.-A. (2013). «Les emplois non pourvus : mythes et réalités. » Regards croisés sur l'économie, 13, 151-167.

Fagan, C., Hebson, G., and Unit, G. (2006). Making Work Pay. Debates from a Gender Perspective. A Comparative Review of Some Recent Policy Reforms in Thirty European Countries. Luxembourg: Office for Official Publications of the European Communities.

Fagnani, J., Math, A. (2012). «Des assistantes maternelles mieux formées et plus qualifiées. Les parents consentiraient-ils à augmenter la rémunération ?» Politiques sociales et familiales, 109, 59-73.

Fernandez-Macias, E. (2012). "Job Polarization in Europe? Changes in the Employment Structure and Job Quality, 1995-2007.” Work and Occupations, (39)2, 157-182.

Folbre, N. (2001). The Invisible Heart: Economics and Family Values. New York: The New Press.

GAdRey, J. (2003). Socio-économie des services, 3rd ed. Paris: La Découverte. 
Gadrey, N., Jany-Catrice, F., and Pernod-Lemattre, M. (2004). «Les non-qualifiés : qui sont-ils ?» In D. MÉDA, F. VENNAT, Le Travail non qualifié. Permanences et paradoxes (pp. 166181). Paris: La Découverte.

Gadrey, N., Jany-Catrice, F., and Pernod-Lemattre, M. (2009). « Employés non qualifiés : la catégorie oubliée des politiques d'égalité professionnelle. » Économies et sociétés, série « Socio-économie du travail », 30, 57-86.

Gautié, J., Margolis, D. (2009). «L'impact de la politique publique sur le marché du travail à bas salaire : offre, demande et qualité de l'emploi. » Économie et statistique, 429-430, 3-19.

Gollac, M., Volkoff, S. (2006). La perception subjective du travail: rôle des identités de genre et des conditions d'emploi (quelques éléments d'analyse statistique). Document de travail, no 69, Noisy-le-Grand: Centre d'études de l'emploi.

Gordon, D. M., Edwards, R., and ReICH, M. (1982). Segmented Work, Divided Workers: The Historical Transformation of Labor in the United States. Cambridge: Cambridge University Press.

Grimshaw, D., Cartwright, J., KeIZer, A., and Rubery, J. (2014). Coming Clean: Procurement and Contract Practices in Commercial Cleaning. Equalities and Human Rights Commission, Manchester, EHRC.

Guilbert, M. (1966). Les Fonctions des femmes dans l'industrie. Paris: Mouton et Cie .

HaAkKestad, H., Fridberg, J. H. (2017). "Deskilling Revisited: Labour Migration, NeoTaylorism and the Degradation of Craft Work in the Norwegian Construction Industry." Economic and Industrial Democracy [online]: https://doi.org/10.1177\%2F0143831X17735671.

Hély, M. (2009). Les Métamorphoses du monde associatif. Paris: Presses universitaires de France.

Hipp, L., Bernhardt, J., and Allmendinger, J. (2015). "Institutions and the Prevalence of Nonstandard Employment.” Socio-Economic Review, (13)2, 351-377.

Holley, S., Rainnie, A. (2012). "Who Cleans Up? The Declining Earnings Position of Cleaners in Australia." The Economic and Labour Relations Review, (23)1, 143-160.

IBos, C. (2013). «Quand la garde d'enfants se mondialise. » Plein droit, 96, 7-10.

JAEhrling, K., MÉHAut, P. (2013). “'Varieties of Institutional Avoidance': Employers' Strategies in Low-Waged Service Sector Occupations in France and Germany." Socio-Economic Review, (11)4, 687-710.

JANY-CATRICE, F. (2010). «La construction sociale du "secteur" des services à la personne: une banalisation programmée ? sociologie du travail, (52)4, 521-537.

Jolly, C. (2015). La polarisation des emplois : une réalité américaine plus qu'européenne? Document de travail, no 2015-04, France Stratégie.

Jounin, N. (2009). Chantier interdit au public. Enquête parmi les travailleurs du bâtiment. Paris: La Découverte.

Kalleberg, A. (2011). Good Jobs, Bad Jobs. New York: Russel Sage Foundation. 
Kulanthaivelu, É. (2018). «Les services à la personne en 2016. L'activité se stabilise. » Dares résultats, no 017.

Lamotte, B., Puissant, E. (2010), Recherche-action La précarité dans l'emploi, nouvelles formes d'emploi et de travail dans l'aide à domicile. Contribution to the final report on the programme.

LAmotte, B., Puissant, E. (2013). Recherche-action Sécurisation des parcours professionnels et dialogue social territorial dans le secteur de l'aide à domicile. Contribution to the final report on the programme.

LE Roy, A., PuISSANT, E. (2016). «Évolution des référentiels politiques dans l'aide à domicile. » RECMA, 342, 69-84.

LEFEBVRE, M. (2012). Qualité(s) de l'emploi dans les services à la personne: entre régulations publiques et professionnelles. (Thèse de doctorat en économie, Université Lille 1).

Marglin, S. (1974). “What bosses do?” Review of Radical Political Economics, (6)2, 60-112.

Marsden, D. (1999). A Theory of Employment Systems. Oxford: Oxford University Press.

Martin-HuAn, J. (1997). La Longue Marche des domestiques en France : du XIX é siècle à nos jours. Nantes: Opéra éditions.

Maruani, M., Nicole-Drancourt, C. (1989). Au labeur des dames : métiers masculins, emplois féminins. Paris: Syros-Alternatives.

MARX, K. (1867). Le Capital. Euvres I. Paris: Gallimard.

MÉDA, D., PÉRIVIER, H. (2007). Le Deuxième Âge de l'émancipation. La société, les femmes et l'emploi. Paris: Seuil.

Méda, D., Vennat, F. (2004). Le Travail non qualifié. Permanences et paradoxes. Paris: La Découverte.

Messing, K., Chatigny, C., and Courville, J. (1998). “'Light' and 'Heavy' Work in the Housekeeping Service of a Hospital.” Applied Ergonomics, (29)6, 451-459.

Messing, K., Doniol-Shaw, G., Hä̈ntJens, C. (1993). "Sugar and Spice and Everything Nice: Health Effects of the Sexual Division of Labor among Train Cleaners." International Journal of Health Services, (23)1, 133-146.

Nirello, L. (2015). La Construction problématique de la relation d'emploi dans l'ESS : les Ehpad, entre régulations publiques et régulations d'entreprise. (Thèse de doctorat en économie, Université de Nantes).

Nkouatchet, R. N. (2005). « La précarité de l'emploi au service de la prospérité du fast-food. » Sociologie du travail, (47)4, 470-484.

Oesch, D., Menes, J. (2011). "Upgrading or Polarization? Occupational Change in Britain, Germany, Spain and Switzerland, 1990-2008.” Socio-Economic Review, (9)3, 503-531.

Perraudin, C., Thèvenot, N., Tinel, B., Valentin, J. (2006). « Sous-traitance dans l'industrie et ineffectivité du droit du travail : une analyse économique. » Économie et institutions, 9, 35-55. 
Puissant, E. (2010). La Relation associative d'aide à domicile: spécificités, remises en cause, résistances. (Thèse de doctorat en économie, Université de Grenoble).

Puissant, E. (2011). «Le rôle ambivalent des associations d'aide à domicile dans la professionnalisation des emplois et des salariées. » Formation emploi, 115, 37-50.

Rose, J. (2012). Qu'est-ce que le travail non qualifié ? Paris: La Dispute.

Roux, N. (2018). De l'emploi stable au travail insoutenable. Trajectoires d'ouvrières agricoles en groupement d'employeurs. Document de travail, no 196, Centre d'études de l'emploi et du travail.

ThiÉRuS, L. (2014). «Les services à la personne en 2012. Baisse de l'activité, sauf dans les entreprises prestataires. » Dares analyses, no 038.

TIRMARCHE-ISSEMANN, A. (2011). L'Institutionnalisation de la fonction d'assistante maternelle. La reconfiguration de l'économie domestique. (Thèse de doctorat en sociologie, Université de Strasbourg.

TRABUT, L. (2014). «Aides à domicile: la formation améliore-t-elle l'emploi ? », Formation emploi, 127, 71-90.

VATAN, S. (2014). La Tarification des services d'aide à domicile : une analyse institutionnaliste par le rôle paramétrique du prix. (Thèse de doctorat en économie, Université Lille 1).

VOZARI, A.-S. (2014). « Recruter de "bonnes” assistantes maternelles. La sélection à l'entrée d'un emploi féminin non qualifié. » Sociétés contemporaines, 95, 29-54.

Western, B., Healy, K. (1999). "Explaining the OECD Wage Slowdown Recession or Labour Decline?" European Sociological Review, (15)3, 233-249.

Zajdela, H. (2009). « Comment et pourquoi activer les inactifs ? "Travail et Emploi, 118, 69-76.

Zock, J. P. (2005). "World at Work: Cleaners." Occupational and Environmental Medicine, (62)8, 581-584. 


\section{ApPendix - Main Empirical Materials}

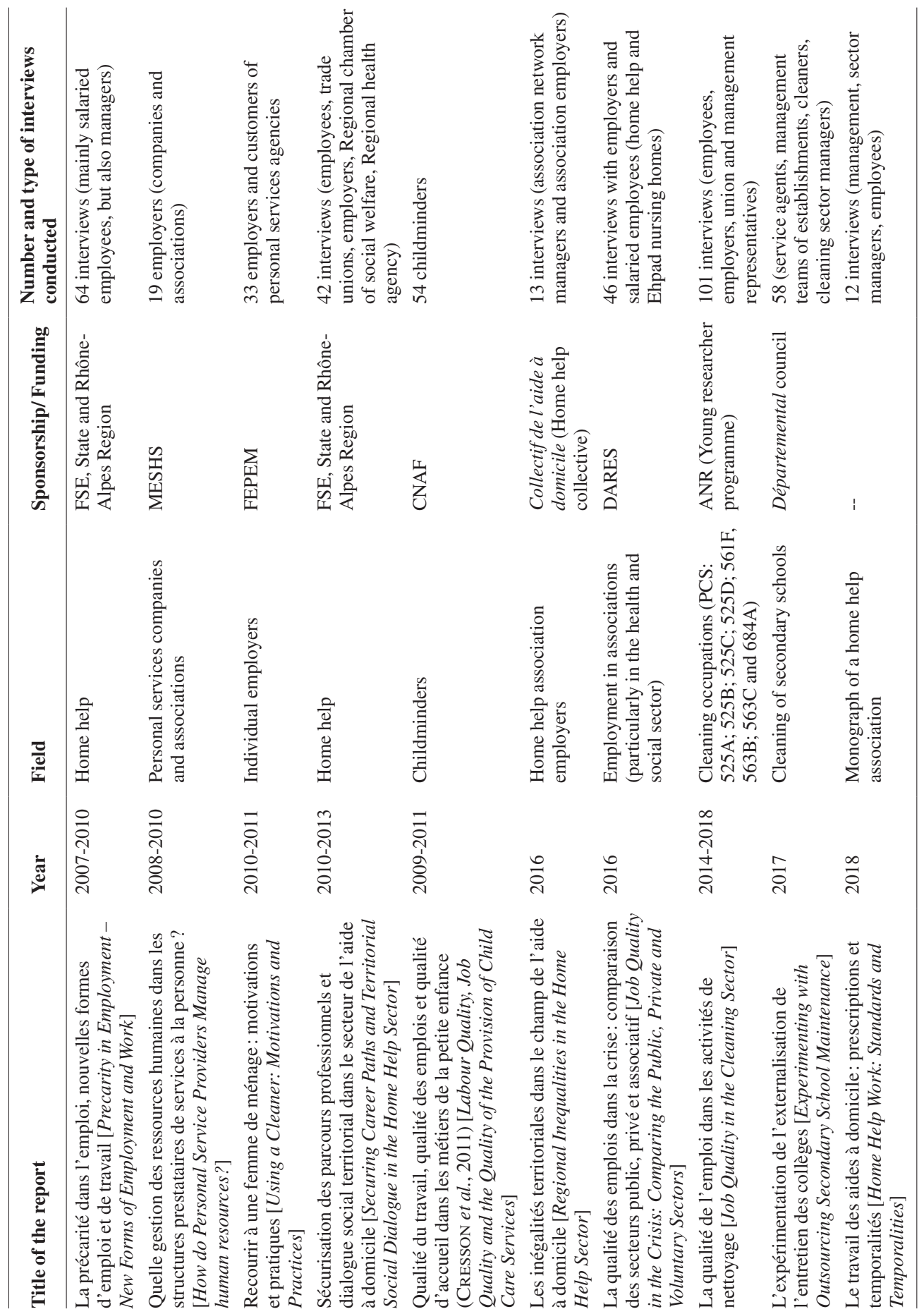


